\title{
CONSTRUÇÃO DE BASE DE DADOS DIGITAL PARA ESTUDO DA ANATOMIA EQUINA
}

(Construction of a digital database for study of the horse anatomy)

\author{
Daniela Góes Turchenski, Acir José Da Silva Franco, Flávio De Almeida e Silva, Pedro Vicente Michelotto \\ Junior, Edson José Rodrigues Justino
}

Pontifícia Universidade Católica do Paraná, Curitiba, Paraná, Brasil.

\author{
*Correspondência: danielaagoes@hotmail.com
}

RESUMO: O estudo da anatomia é essencial para as profissões da área da saúde e, baseadas nas reformas éticas e ambientais que estão ocorrendo, as universidades buscam por métodos alternativos e mais sustentáveis no ensino dessa disciplina. Seguindo esta proposta, a PUCPR criou uma mesa digital para auxiliar no ensino e aprendizagem da anatomia. Com a finalidade de incremento da base de dados digital desta tecnologia, este projeto teve o objetivo de produzir material anatômico de membro torácico da espécie equina (MTE) para ser submetido ao escaneamento em três dimensões (3D) e selecionar o melhor método de fixação para esse fim. Para a criação dessas peças foi utilizado um MTE o qual já era pertencente ao acervo da universidade. A peça foi coletada a fresco e logo em seguida congelada. Para o projeto, o membro foi descongelado e submetido a formolização com a injeção de formol $10 \%$ e, na sequência foi totalmente imergido durante 4 dias em formol 15\%. Após esse processo o membro foi recongelado. Ainda congelado, o MTE foi seccionado transversalmente em três partes, por intermédio de um corte em região metafisária distal de rádio e outro em região proximal metacarpiana. Os dois cortes mais distais resultantes foram novamente seccionados no plano mediano, totalizando quatro peças para o processo de escaneamento, e a peça mais proximal foi utilizada no teste de fixação. As peças para o escaneamento foram novamente imersas por 24 horas em solução contendo formol:glicerina:água (1:5:5) e depois foram acondicionadas em ambiente ventilado para secar em temperatura ambiente por oito dias. Após esse processo, foi feito o escaneamento 3D das peças. A peça mais proximal do MTE foi dividida em 31 secções transversais de $0,5 \mathrm{~cm}$ de espessura cada, as quais foram separadas e imersas durante três dias em quatro diferentes soluções: solução salina hipersaturada, formol:glicerina:água e solução de Larssen. Após o tempo de imersão nas soluções designadas, permaneceram três dias secando em temperatura ambiente. Foram realizadas fotos de todos os metâmeros fixados e estas imagens foram avaliadas entre si quanto á cor de musculatura, de medula óssea e de osso cortical pela comparação de histogramas em HSV (matriz, saturação, brilho). Também foi comparada a desidratação das peças por mensuração no AutoCAD ${ }^{\circledR}$ dos espaços entre as estruturas produzidos pela secagem. Foi atribuído um número do teste de Fibonacci para cada parâmetro estudado, sendo 13 o valor com características mais inferiores e 1 o valor de melhor qualidade. Os melhores resultados desse estudo foram: a solução salina hipersaturada no quesito manutenção da cor e a solução de glicerina pura em relação a desidratação. Apesar dos resultados, todos os processos de fixação apresentaram alteração de coloração quando comparados com a peça original. De forma geral, a digitalização de peças anatômicas fixadas é uma alternativa pertinente e com interessante proposta dentro do binômio ensino-aprendizagem, pois essa tecnologia pode auxiliar professores e estudantes tanto nas aulas práticas quanto teóricas, facilitando o acesso ao acervo do laboratório de anatomia em forma digital e em 3D.

Palavras-chave: anatomia do cavalo; coloração; desidratação; peça anatômica; solução de fixação. 